\title{
Reproduction and cycle of gonadal development in the Mediterranean gorgonian Paramuricea clavata
}

\author{
Rafel Coma ${ }^{1,2}$, Marta Ribes ${ }^{1}$, Mikel Zabala ${ }^{2}$, Josep-Maria Gili ${ }^{1}$ \\ ${ }^{1}$ Institut de Ciències del Mar (CSIC), Passeig Joan de Borbó s/n, E-08039 Barcelona, Spain \\ ${ }^{2}$ Department d'Ecologia, Universitat de Barcelona, Avda, Diagonal 645, E-08028 Barcelona, Spain
}

\begin{abstract}
Paramuricea clavata (Risso, 1826) is a typical gorgonian species of sublittoral communities found on rocky substrates in the Mediterranean Sea. The reproductive biology of this species was studied from 1990 to 1992 off the Medes Islands (northwestern Mediterranean). P. clavata is dioecious. The sex ratio was $1: 1$. Oogenesis lasted 13 and $18 \mathrm{mo}$, beginning between February and July and culminating in the release of 13 ( $\mathrm{SD}=2.2)$ mature eggs per polyp during the summer (June to July) of the following year. Maximum egg diameter varied between 400 and $500 \mu \mathrm{m}$. Male gonads appeared in January and ripened in a much shorter time, 6 to $7 \mathrm{mo}$. Maximum spermary diameter ranged from 500 to $750 \mu \mathrm{m}$. Male gonadal volume per polyp was larger than female gonadal volume. P. clavata is a perennial, iteroparous species. Reproduction was synchronous each year. Over the $3 \mathrm{yr}$ study period spawning took place during 2 discrete week-long periods in June and July. Spawning occurred at the end of May coinciding with increasing water temperature and correlated with the lunar cycle wherein spawning also occurred 3 to $6 \mathrm{~d}$ after the full moon or the new moon. Spawned eggs adhered, through the action of a mucous coating, to the outer surfaces of the female colonies. Embryonic development in P. clavata was relatively uncommon. Embryogeny (total and equal cleavage) and final maturation of the planulae took place among the polyps. On leaving the surface of the colonies, larvae immediately settled on the surrounding substrate. Asexual reproduction was negligible and the maintenance of the population is based on sexual reproduction.
\end{abstract}

KEY WORDS: Gorgonians - Reproduction · Gonad development - Sex ratio - Spawning · Fecundity * Mediterranean

\section{INTRODUCTION}

Gorgonians are modular colonial marine invertebrates which commonly reproduce both sexually and asexually. Their dual forms of reproduction endow them with the flexibility to develop highly varied ecological strategies (Jackson 1977, 1985, Hughes \& Jackson 1980). In highly saturated and stable benthic habitats, in which modular organisms are prevalent (Jackson 1977, 1985), asexual reproduction suffices to maintain most invertebrate populations including gorgonians (Hughes 1985). Other features related to reproduction have also been considered as fitting the general pattern for modular marine invertebrates: (1) separation of the sexes and the sex ratio (Benayahu et al. 1990); (2) semelparity, iteroparity, and size at first reproduction in association with demographic para- meters (Hughes \& Cancino 1985); (3) the method of ripening and spawning (Thorson 1950, Jackson 1985); and (4) morphology, feeding, and life-span of larvae (Strathmann 1980, Kojis \& Quinn 1981, Jackson 1985). While these features tend to hold true for modular marine invertebrates, many exceptions can be found when taxa are analyzed in detail (Sebens 1982).

These features are well illustrated by the gorgonians. The substantial body of work carried out in the Caribbean Sea (Kinzie 1970, 1974, Goldberg \& Hamilton 1974, Behety-González \& Guardiola 1979, Martin 1982, Brazeau \& Lasker 1989, 1990) contrasts with the largely undescribed reproduction of Mediterranean gorgonians, although interesting features of the sexual reproduction of certain species, such as Eunicella singularis (Theodor 1967, Weinberg \& Weinberg 1979) and Corallium rubrum (Vighi 1970), have been described. 
The object of this paper is to describe the reproductive biology of the Mediterranean gorgonian Paramuricea clavata and to compare this with the features and patterns of reproduction already described for warm-water species. To this end, information is provided on the asexual reproduction, sex ratio, size at first reproduction, morphology, gonadal development cycle, method of fertilization, brooding of larvae, and spawning periods.

\section{MATERIAL AND METHODS}

The population of Paramuricea clavata located near the Carall Bernat (Medes Islands, northwestern Mediterrean: $\left.43^{\circ} 2^{\prime} 30^{\prime \prime} \mathrm{N}, 3^{\circ} 13^{\prime} 30^{\prime \prime} \mathrm{E}\right)$ was studied from 1990 to 1992 . The population is located at depths between 15 and $27 \mathrm{~m}$ and occupies a surface area of approximately $1000 \mathrm{~m}^{2}$.

Sampling. Samples from the population were collected at a depth of 17 to $19 \mathrm{~m}$ by a SCUBA diver. Maximum height (distance from the base to the farthest point) of all colonies sampled was measured to the nearest $0.5 \mathrm{~cm}$. Samples consisted of either whole colonies or apical fragments and were immediately fixed in $10 \%$ formalin in sea water. In the laboratory, polyps were dissected under a binocular dissecting microscope, and the number of gonads and gonadal diameter were recorded for each polyp. Gonadal volume was estimated for each polyp for both sexes.

Asexual reproduction. Asexual reproduction in gorgonians occurs mainly through fragmentation and stolonization. Colonies that have originated through fragmentation are usually attached to the substrate at several points and often have several parallel branches growing up from a branch lying on the substrate. These colonies are distinctly different in appearance from those developing from larvae. Colonies of larval origin have a single point of attachment and a single branch rising from the base. Colonies with connections to other colonies are thought to have originated from stolons.

To assess the impact of stolonization, connections in 50 colonies smaller than $15 \mathrm{~cm}$ in height [stolonal connections between larger colonies of several species degenerate (Lasker 1983)] were studied along a linear transect laid out over the community, between 17 and $25 \mathrm{~m}$ depth, using measuring tapes.

Sexual reproduction. Fecundity variability and sample size: To determine variations in polyp fecundity (number of gonads produced per polyp) depending on polyp position within the colony, 3 male and 3 female colonies, ranging in height from 35 to $45 \mathrm{~cm}$, were randomly collected at the end of May 1990. All gonads greater than $200 \mu \mathrm{m}$ from 10 polyps of 3 distal and 3 internal fragments of each of these colonies were measured. Colonies of different sex were identified in the field by scraping a polyp and observing the color of the gonads (yellow in males and blue in females; Fig. 1).

At the begining of June, a distal portion $(5 \mathrm{~cm}$ from the tip) of 20 colonies ( 10 male and 10 female), ranging in height from 35 to $45 \mathrm{~cm}$, was randomly collected. Only branches of first order were distal. Five polyps of each fragment were examined and all gonads greater than $200 \mu \mathrm{m}$ were measured. The values recorded were recombined into sample groups of

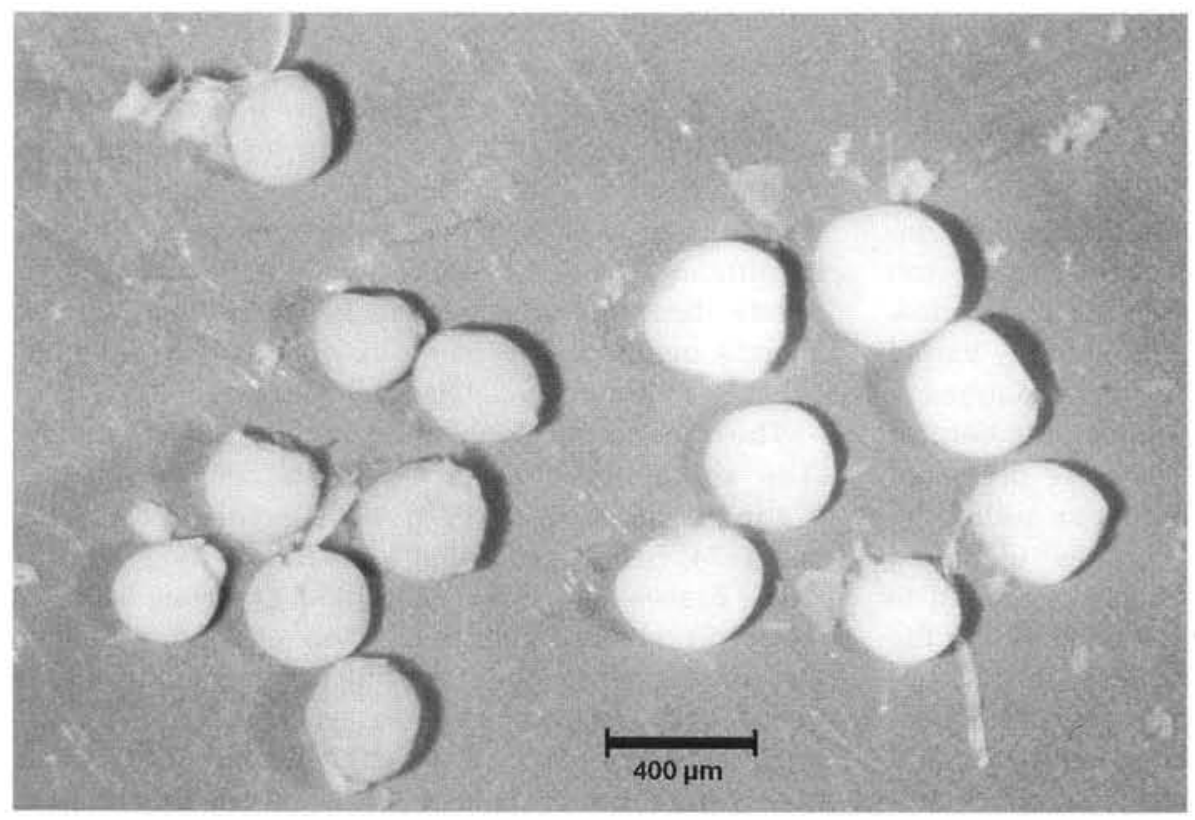

Fig. 1. Sexual reproduction in Paramuricea clavata: male gonads ( 7 sperm sacs on right, yellow in the field) and female gonads ( 8 ovaries on left, bright blue color in the field). The ovaries in ripeness $(>200 \mu \mathrm{m})$ contain a single oocyte surrounded by a thin endodermal layer. When gonad diameter is $<150 \mu \mathrm{m}$, sex is discernible only by means of histological slices. At diameters $>150 \mu \mathrm{m}$, sex determination is possible based on colour and appearance 
increasing size of $5,10,15,20,25,30,35,40,45$ and 50 polyps and the coefficient of variation (variance/ mean fecundity) calculated for each. The curve for the coefficient of variation versus sample size was evaluated to determine the minimum representative sample size.

Sex ratio: Sex ratio samples were collected in May and June 1991, just before spawning. A total of 302 colonies, ranging from 1 to $55 \mathrm{~cm}$ in height and located along randomly selected linear transects $50 \mathrm{~m}$ long, were examined. Minimum distance between sampled colonies was $1 \mathrm{~m}$. Fifty of the colonies were tagged to determine possible sex changes, and a distal portion of each of these colonies was collected in May 1990, 1991 and 1992.

Reproductive cycle: To study the annual reproductive cycle of Paramuricea clavata, 20 colonies (10 male and 10 female) were tagged. A distal portion of each of these colonies was collected monthly from July 1990 to May 1991. In June and July 1991, during the spawning period, sampling was carried out every 2 wk. The number and diameter of all gonads present in 5 randomly selected polyps on each distal portion and sample were examined as described above. Cohorts of eggs were identified from following the size-frequency distribution of gonad diameter with the Bhattacharya method (Bhattacharya 1967) of the program ELEFAN (Gayanilo et al. 1989).

Timing of spawning: To pinpoint the timing of spawning and to quantify the percentage of female colonies spawning, linear transects were laid out randomly and the first 100 colonies larger than $20 \mathrm{~cm}$ in height were examined weekly for surface brooded eggs, from May to August in 1990, 1991 and 1992.

\section{RESULTS}

\section{Fecundity variability and sample size}

Polyps from both distal and internal zones contained ripe gonads. Ripening of polyps within the colony was highly synchronous, but polyps from distal fragments $[\bar{x}=25.7 \pm 4.2(\mathrm{SD})$ gonads per polyp $]$ had a significantly higher fecundity than those from inner fragments $(\bar{x}=14.3 \pm 4.8$ gonads per polyp) (ANOVA, $\mathrm{p}<$ $0.001)$ regardless of sex. Significant differences in polyp fecundity were observed between colonies (ANOVA, $\mathrm{p}<0.001$ ).

The coefficient of variation of polyp fecundity decreased quickly with increasing sample size in both male and female polyps (Fig. 2). The curve flattens out from a sample size of 30 polyps (male colonies) and 40 polyps (female colonies). Based on these sample sizes, the variance was less than $5 \%$ of the mean. These
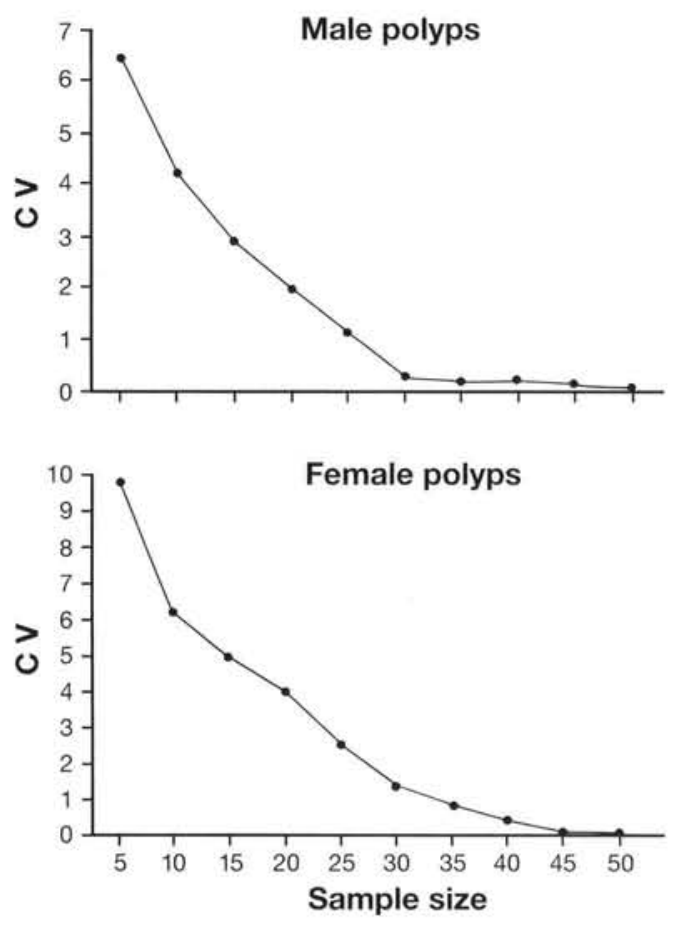

Fig. 2. Paramuricea clavata. Coefficient of variation (CV: variance/mean) of fecundity per polyp curve to determine the minimum sample size

results make it possible to state with confidence that the sample size used in this study was sufficient to represent the population as a whole.

\section{Asexual reproduction and sex ratio}

Only 1 of the 307 colonies $(0.3 \%)$ found in the $9.6 \mathrm{~m}^{2}$ examined area appeared to have developed from fragments. From the examined 50 colonies of height less than $15 \mathrm{~cm}$, only 2 colonies ( $2 \%$ ) were connected by a stolon. These observations demonstrate the low quantitative importance of asexual reproduction in Paramuricea clavata.

The sexes were separated, but no sexual dimorphism between male and female colonies was observed. Hermaphroditic colonies were very uncommon: only 1 of the 302 colonies examined ( $\geq 20 \mathrm{~cm}$ in height) had polyps containing both sperm sacs and oocytes. The sex ratio of females to males recorded was $0.92(145 / 157)$, which was not statistically different from unity (chi-squared, $\mathrm{p}<0.001$ ). The sex ratio did not change significantly for colonies of different size classes of $10 \mathrm{~cm}$ in height $[\bar{x}=1.5 \pm 0.8$ (SD) small colonies, $\bar{x}=7.7 \pm 5.2$ medium colonies, $\bar{x}=14.5 \pm 6.1$ large colonies] (chi-squared, $\mathrm{p}<0.001$ ). No change in sex was recorded for any of the 50 tagged colonies during the 3 yr study period. 


\section{Gonadal development cycle}

Oocyte development

Completion of oocyte development takes between 13 and $18 \mathrm{mo}$, beginning between February and July and culminating in spawning during the summer (June and July) of the following year (Fig. 3, Table 1). Formation of new oocytes is not synchronous, and takes place over a 5 mo period (February to July). Oocyte development is not synchronous either between the colonies within a population or between the polyps of a single colony. The newly formed oocytes can be recognized by their small size, and they remain smaller than $100 \mu \mathrm{m}$ until the beginning of the year after formation, when they begin to ripen. Mean oocyte diameter during ripening increases exponentially from January to the beginning of June. The mean number of oocytes per polyp was statistically constant (13 oocytes per polyp; $\mathrm{SD}=2.2$ ) from commencement of follow-up in July 1990 to release in June 1991 (chi-squared, $\mathrm{p} \leq 0.05$ ). Since new oocytes are generated each year, 2 overlapping cohorts are present from formation of these oocytes in the polyps (February) to release of the mature eggs that formed the year before (June and July).

The oocytes attained peak size in June (Table 1). At this time, female
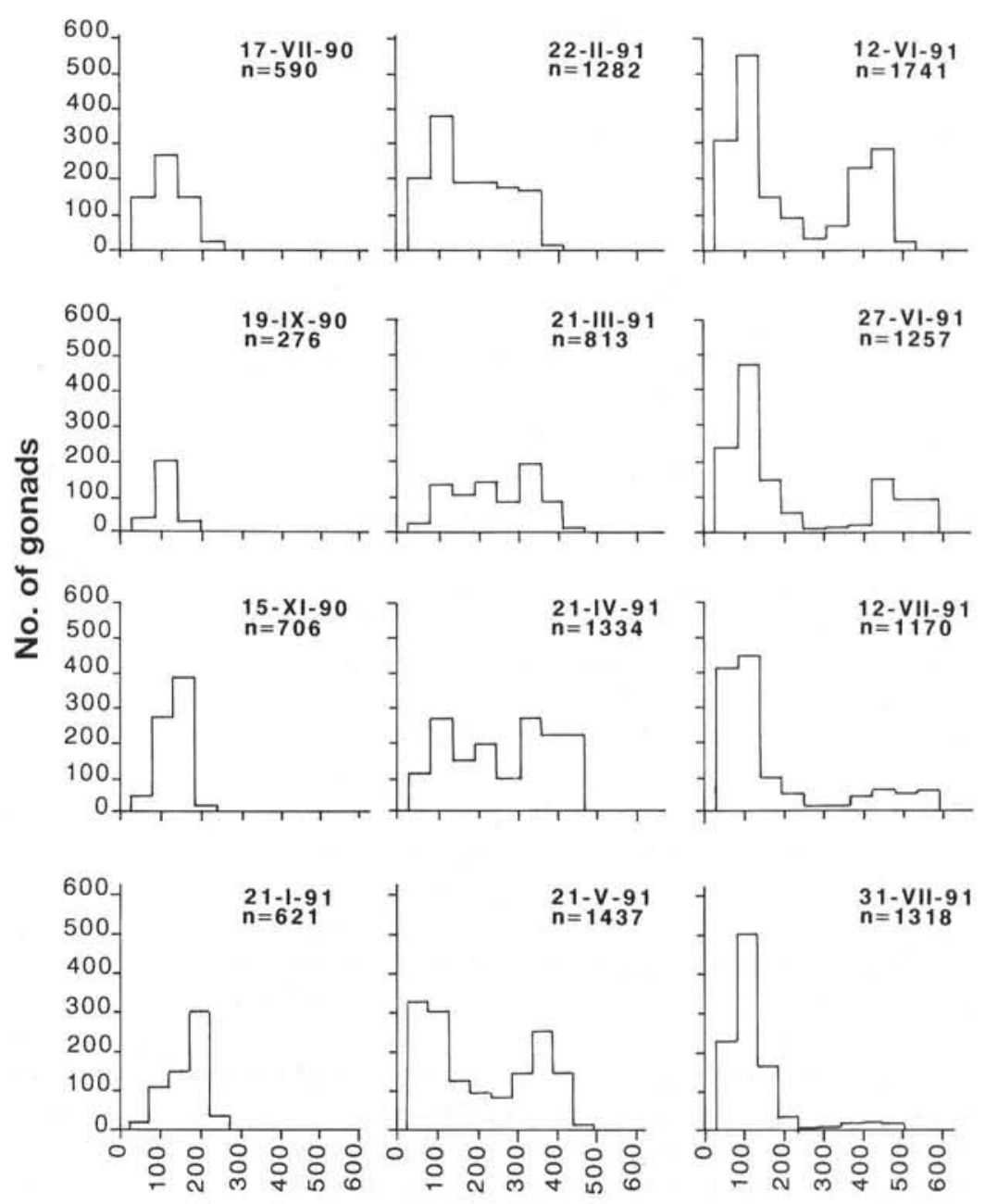

Diameter $(\mu \mathrm{m})$

Fig. 3. Paramuricea clavata. Size-frequency distributions of female gonad diameter in 50 polyps of females in 1990 and 1991. n: total number of gonads. Sampling date shown by day-month (Roman numeral)-year

Table 1. Paramuricea clavata. Evolution of number $(\mathrm{n})$ and mean diameter $\left(\bar{x}, \mathrm{SD}_{\text {; }}\right.$ in $\left.\mu \mathrm{m}\right)$ of the gonads in 50 male polyps and 50 female polyps in 1990 and 1991. Two cohorts are present in the female gonads (Bhattacharya method)

\begin{tabular}{|c|c|c|c|c|c|c|c|c|c|}
\hline \multirow[t]{3}{*}{ Date } & \multicolumn{6}{|c|}{ Female } & \multirow{2}{*}{\multicolumn{3}{|c|}{$\begin{array}{c}\text { Male } \\
\text { Cohort } 1991\end{array}$}} \\
\hline & \multicolumn{3}{|c|}{ Cohort 1990} & & \multicolumn{2}{|c|}{ Cohort 1991} & & & \\
\hline & $\mathrm{n}$ & $\bar{x}$ & SD & $\mathrm{n}$ & $\bar{x}$ & SD & $\mathrm{n}$ & $\bar{X}$ & SD \\
\hline Jul 1990 & 590 & 74 & 45 & - & - & - & - & - & - \\
\hline Sep 1990 & 276 & 72 & 27 & - & - & - & - & - & - \\
\hline Nov 1990 & 706 & 113 & 43 & - & - & - & - & - & - \\
\hline Jan 1991 & 621 & 158 & 38 & - & - & - & - & - & - \\
\hline Feb 1991 & 493 & 217 & 41 & 789 & 74 & 43 & 680 & 77 & 34 \\
\hline Mar 1991 & 521 & 276 & 37 & 292 & 93 & 36 & 509 & 137 & 47 \\
\hline Apr 1991 & 793 & 291 & 44 & 541 & 79 & 41 & 1182 & 203 & 74 \\
\hline May 1991 & 679 & 313 & 50 & 758 & 44 & 56 & 1087 & 258 & 102 \\
\hline Jun 1991 & 731 & 342 & 43 & 1010 & 65 & 36 & 1725 & 281 & 129 \\
\hline Jun 1991 & 371 & 388 & 33 & 886 & 69 & 37 & 1558 & 326 & 108 \\
\hline Jul 1991 & 243 & 425 & 76 & 927 & 52 & 39 & 623 & 315 & 85 \\
\hline Jul 1991 & 86 & 380 & 75 & 1376 & 72 & 29 & 117 & 284 & 54 \\
\hline
\end{tabular}


colonies showed a remarkable synchronization in ripeness, and by the end of June and beginning of July, all oocytes larger than $200 \mu \mathrm{m}$ had disappeared. The number and diameter of oocytes at the beginning of June permits the estimation of the annual production of female gametes.

\section{Testes development}

The male reproductive cycle was considerably shorter (Fig. 4, Table 1), but gonadal volume was in all cases higher in males than in females. No male gonads were discernible until the beginning of the year (January and February). The mean number of spermaries per polyp was $4.3(\mathrm{SD}=0.8)$ in January. Spermaries increased rapidly in number and in diameter, to 24 spermaries per polyp $(\mathrm{SD}=5.2)$ in April, with a peak value of $35(\mathrm{SD}=6.1)$ at the beginning of June when gonadal mass occupied up to $80 \%$ of the gastrovascular cavity. From that point spermary volume fell off sharply, coincident with the end of spermatogenesis and release. By mid August no gonads were present in any male polyps. Thus, ripening time for male gonads was approximately 6 to $7 \mathrm{mo}$. A broad range of variation in spermary diameter was observed, with maximum values between 500 and $700 \mu \mathrm{m}$.

\section{Spawning}

Ripening of male and female gonads was highly synchronous and converged at the beginning of June. Over the study period (1990 to 1992) female brooding took place in June and July. There were 2 discrete episodes of brooding, lasting 1 to $8 \mathrm{~d}$, separated by a period of inactivity (Fig. 5). Some colonies observed at the end of brooding exhibited gonads that had failed to ripen, but these in no case exceeded $10 \%$ of the total number of gonads and were at the lower end of the overall range of gonadal diameters.

In 1990 and 1991 male spawning and female brooding occurred between 3 and $6 \mathrm{~d}$ after the full moon or the new moon (Fig. 5). Bad weather in June 1991 prevented direct observation of the onset of spawning and brooding. Nevertheless, the monitoring of gonadal development showed that episodes of release took place between 14 and 18 June and 3 and 8 July in both female (Fig. 6a) and male (Fig. 6b) colonies. In 1992 spawning followed the pattern observed in previous years, with the exception of 2 episodes of spawning, one before and the other after the dates for which they would have been predicted based on the information for preceding years.

In male and female polyps gametes broke the gastrodermal layer and were released into the gastrovascular cavity. Male colonies released spermaries spanning a broad range of diameters (150 to $750 \mu \mathrm{m}$ ). In female colonies almost all oocytes larger than $200 \mu \mathrm{m}$ ripened progressively and were spawned in different
Fig. 4. Paramuricea clavata. Size-frequency distributions of male gonad diameter in 50 polyps of males in 1990 and 1991. n: total number of gonads. Sampling date shown by day-month (Roman numeral)-year 


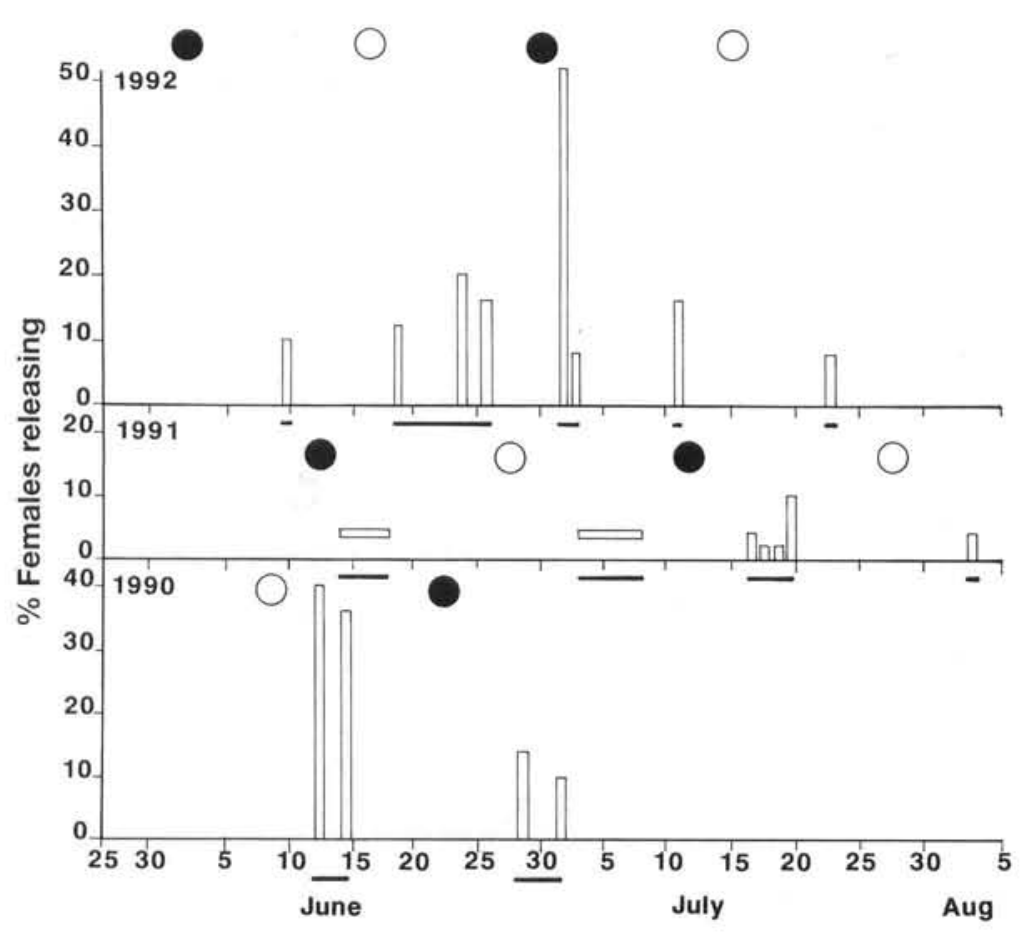

Fig. 5. Paramuricea clavata. Percentage of female colonies observed to be spawning during the spawning periods in 1990, 1991 and 1992. O: full moon; new moon. Solid horizontal lines under dates indicate short periods of continuous observation

episodes. Spawning of male and female gametes was synchronous. Female colonies secreted a mucous material, which bound the eggs together and adhered to the surface of the mother colony (Fig. 7). It was not possible to establish whether or not fertilization took place inside or outside the polyp. The segmentation began in the mucous material adhered to the surface of the mother colony. With time the morulas-mucus masses separated from the colony.

Embryogeny and final maturation of the planulae normally took place on the colony surface. However, strong currents may cause early detachment of the mucous egg mass from the surface of the colony. In that case embryogeny of the larvae takes place at a distance from the mother colony, usually on hard substrata in the immediate vicinity, since both embryos and larvae settle immediately. Cleavage was total and equal.

The first mature planulae appeared $48 \mathrm{~h}$ after spawning. Paramuricea clavata planulae were bright pink as a result of the vitelline reserves that comprised their sole food source during their motile stage. The planulae were pear- or spindle-shaped and measured, on average, $2 \mathrm{~mm}$ in length by $0.5 \mathrm{~mm}$ in width. The epidermis was a ciliated epithelium that afforded the larvae moderate motility. In situ observations indicated that the dispersal stage of larvae was very short; they normally settled rapidly onto the surrounding substratum after remaining in suspension for only a few minutes.

Attachment of the larvae to the substrate and metamorphosis were not observed in situ; however, small colonies consisting of just a few polyps were observable on the substratum $6 \mathrm{mo}$ (January to March) after the summer spawning period.

\section{DISCUSSION}

Many of the features of the reproductive biology of Paramuricea clavata are shared with the Mediterranean Sea gorgonians, Eunicella singularis (Theodor 1967, Weinberg \& Weinberg 1979) and Corallium rubrum (Vighi 1970), but there are also certain differences. The shared aspects are gonochorism, the $1: 1$ sex ratio, internal fertilization or fertilization on the surface of the mother colony, and synchronous spawning. The first 2 aspects also accorded with those of certain species in the Caribbean Sea (Kinzie 1970, 1974, Goldberg \& Hamilton 1974, BehetyGonzález \& Guardiola 1979, Martin 1982) and in the Pacific Ocean (Grigg 1977), the sole exception being the highly skewed sex ratio reported by Brazeau \& Lasker (1990) in the Caribbean gorgonian
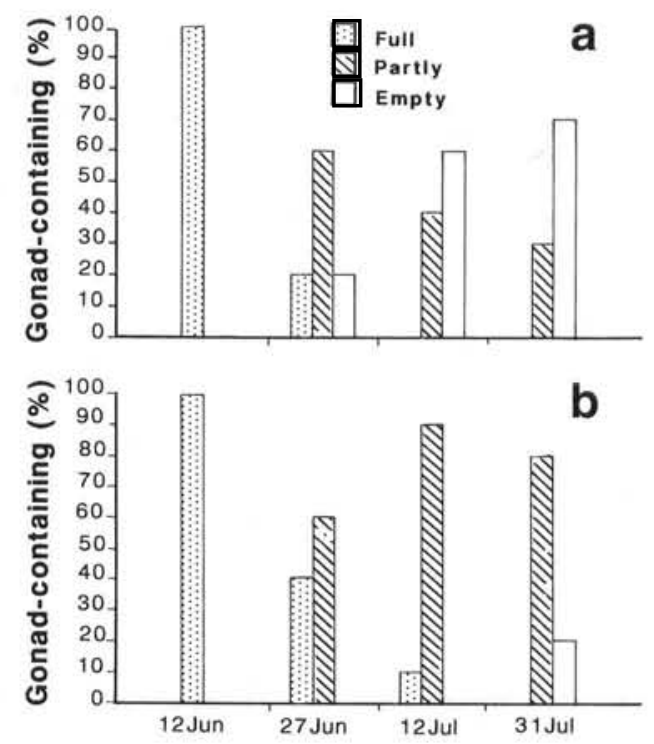

Fig. 6. Paramuricea clavata. Spawning by the polyps on (a) female colonies and (b) male colonies over the 1991 spawning period. Full: colonies which had not yet spawned; partly: colonies in which spawning was partially complete; empty: colonies in which spawning was complete 


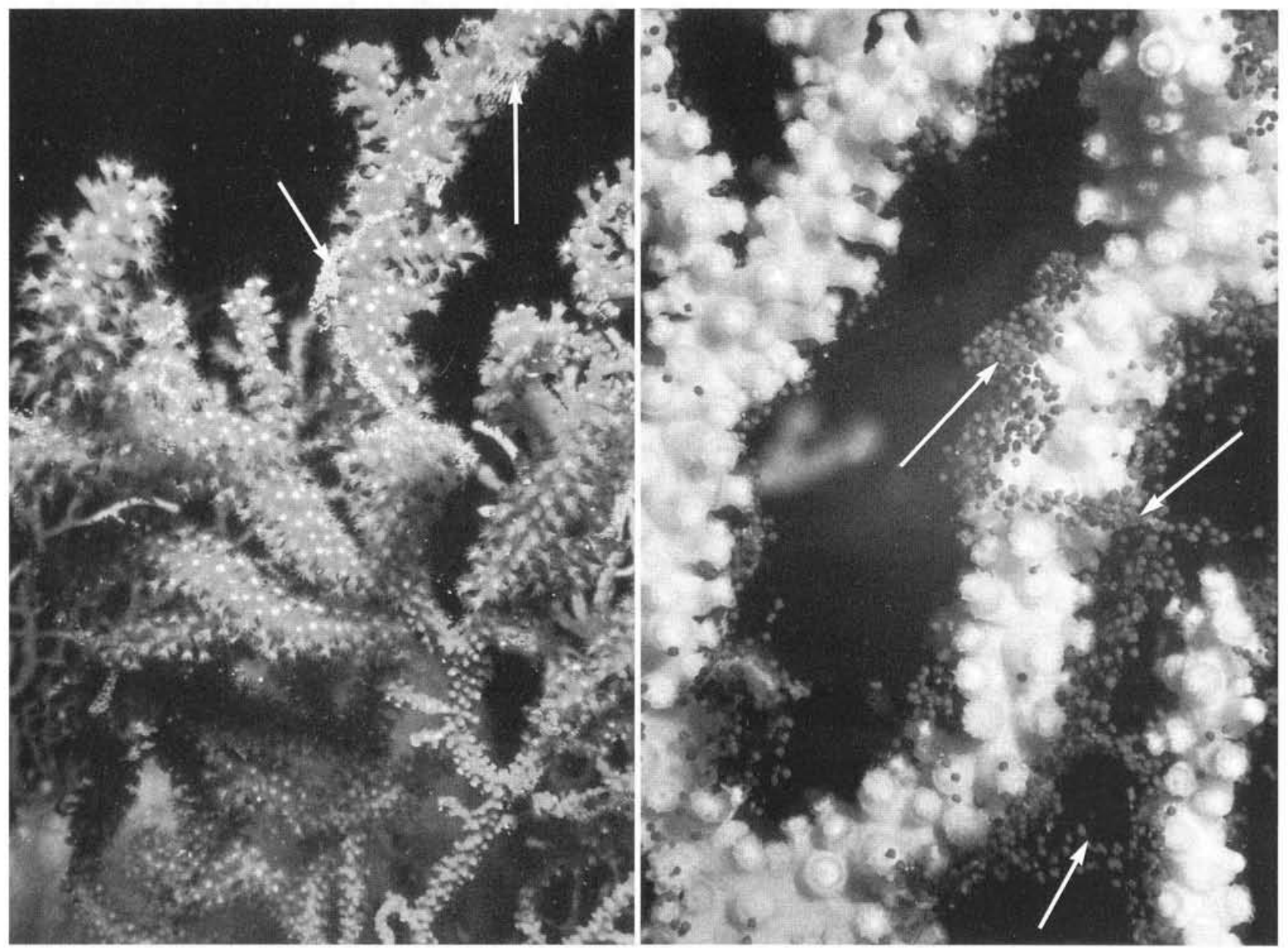

Fig. 7. External brooders (indicated by arrows) in Paramuricea clavata

Briareum asbestinum which is heavily weighted in favour of male colonies (2.2:1). The differences are the small role of asexual dispersal and the singular mode of spawning and the maturation process.

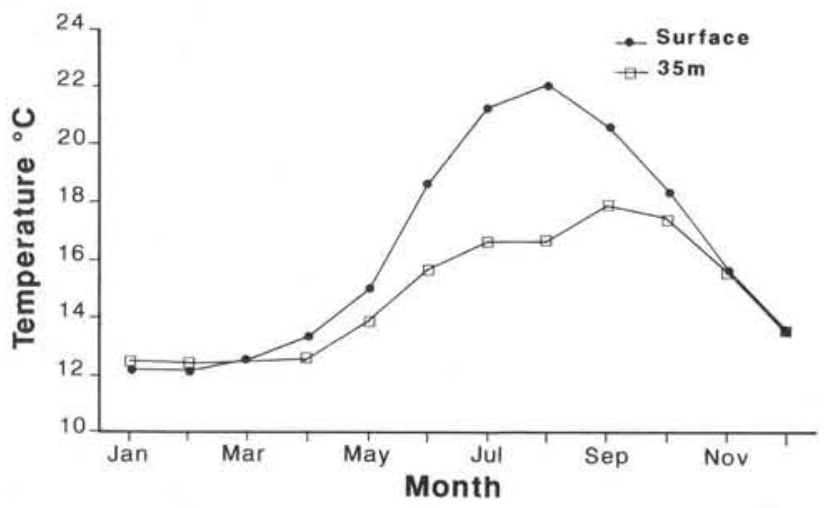

Fig. 8. Mean monthly seawater temperatures $\left({ }^{\circ} \mathrm{C}\right)$ at the surface and at a depth of $35 \mathrm{~m}$ off the Medes Islands (Pascual \& Flos 1984)
Asexual reproduction by stolonization in Paramuricea clavata was negligible in quantitative terms. The lower regeneration capacity after fragmentation showed the inefficiency of this asexual reproduction mechanism in the species (Coma 1994). The lack of colonies originating from fragments may be because colonies seldom fragment or also because there is an inability of fragments to reattach to the substrate (regenerate). Evidence for the quantitatively important role of asexual reproduction in the dispersal of gorgonians has mainly been furnished by studies on tropical species. Lasker (1983) observed that between 20 and $60 \%$ of Briareum asbestinum colonies had arisen through stolonization; in Plexaura A the percentage of colonies arising through asexual means, chiefly fragmentation, was $94 \%$ (Lasker 1984). Asexual reproduction was also important in Junceella fragilis (Walter \& Bull 1983). P. clavata differs radically from tropical species in this respect since vegetative dispersal was negligible in quantitative terms. 


\section{Spawning cycle}

Paramuricea clavata is iteroparous and reproduces annually. The longer duration of oogenesis as compared to spermatogenesis is a common feature of gonadal development in all gorgonian species described to date. Egg development is ordinarily longer than spermary development in octocorals (Benayahu \& Loya 1984, 1986). This is also the general pattern in alcyonaceans (Benayahu et al. 1990) and in many scleractinians (Kojis \& Quinn 1981, 1982, Szmant 1986). This pattern results in the delayed onset of spermatogenesis, with a view to achieving synchronous spawning by the 2 sexes and thus minimizing the loss of gametes (Harrison \& Wallace 1990) (because spermatogenesis takes less time than oogenesis).

The number of offspring per year is generally related to environmental characteristics and tends to be higher in temperate and climatically less stable regions than in the tropics (Margalef 1984). The high number of gonads and gonadal volume values recorded for polyps of both sexes suggest that the expenditure of this species on sexual reproduction is high. Maximum egg size was small compared to the sizes reported for other species (Table 2) but is reasonable in terms of the large number of gonads per polyp. The volume of spermaries is greater than that of female gonads in
Paramuricea clavata and would appear to represent a partial difference in reproductive strategy as compared to Briareum asbestinum (in which gonadal volume is higher in female polyps than in male polyps; Brazeau \& Lasker 1990). Although given the same energy investment males may produce more gonads, it is possible that by increasing the production of male gametes $P$. clavata enhances the likelihood of fertilization.

\section{Fertilization and incubation}

The results of the present study suggest that the reproductive behaviour of Paramuricea clavata is rather unique among anthozoans, halfway between the 2 extremes of oviparity and viviparity. Behaviour basically coincided with the model of external reproduction known as surface brooding, found by Benayahu \& Loya (1983) in Parerythropodium fulvum fulvum and by Brazeau \& Lasker (1990) in Briareum asbestinum. We were not able to determine whether fertilization occurred inside the polyps (internally) or on the surface of the mother colony (externally). Both options have been described in octocorals that incubate their embryos on the surface of the colonies. Fertilization is internal in B. asbestinum (Brazeau \&

Table 2. Mode of reproduction, fertilization, sex ratio, duration of oogenesis and spermatogenesis, maximum egg diameter, number of mature eggs per polyp, and age at first reproduction in the different gorgonian species studied to date

\begin{tabular}{|c|c|c|c|c|c|c|c|c|c|c|}
\hline Species & $\begin{array}{l}\text { Mode of } \\
\text { repro- } \\
\text { duction }\end{array}$ & $\begin{array}{l}\text { Fertili- } \\
\text { zation }\end{array}$ & $\begin{array}{l}\text { Sex } \\
\text { ratio }\end{array}$ & $\begin{array}{l}\text { Dur. of } \\
\text { oogen- } \\
\text { esis } \\
\text { (mo) }\end{array}$ & $\begin{array}{l}\text { Dur. of } \\
\text { spermato- } \\
\text { genesis } \\
\text { (mo) }\end{array}$ & $\begin{array}{c}\text { Max. } \\
\text { oocyte } \\
\text { diameter } \\
(\mu \mathrm{m})\end{array}$ & $\begin{array}{l}\text { No. of } \\
\text { eggs per } \\
\text { mature } \\
\text { polyp }\end{array}$ & $\begin{array}{l}\quad \mathrm{Fi} \\
\text { reproc } \\
\text { Size } \\
(\mathrm{cm})\end{array}$ & $\begin{array}{l}\text { rst } \\
\text { luction } \\
\text { Age } \\
\text { (yr) }\end{array}$ & Source \\
\hline $\begin{array}{l}\text { Corallium } \\
\text { rubrum }\end{array}$ & Internal & Internal & $1: 1$ & 24 & 12 & $300-330$ & $3-6$ & - & - & Vighi (1970) \\
\hline $\begin{array}{l}\text { Eunicella } \\
\text { singularis }\end{array}$ & Internal & Internal & - & - & - & - & 4 & - & - & Theodor (1967) \\
\hline $\begin{array}{l}\text { Paramuricea } \\
\text { clavata }\end{array}$ & $\begin{array}{l}\text { Surface } \\
\text { brooding }\end{array}$ & Internal & $1: 1$ & $13-18$ & $6-7$ & $400-500$ & 13 & 11 & $6-13$ & This study \\
\hline $\begin{array}{l}\text { Muricea } \\
\text { californica }\end{array}$ & Internal & Internal & $1: 1$ & - & - & 700 & 1.6 & 25 & 10 & Grigg (1977) \\
\hline M. fructicosa & Internal & Internal & $1: 1$ & - & - & 600 & 3.8 & 25 & 5 & Grigg (1977) \\
\hline $\begin{array}{l}\text { Plexaura } \\
\text { homomalla }\end{array}$ & External & External & $1: 1$ & 18 & $6-8$ & $315-640$ & 2 & $25-35$ & $4-11$ & Martin (1982) \\
\hline Plexaura A & External & External & - & 20 & - & $500-600$ & 1.9 & 20 & 5 & $\begin{array}{l}\text { Brazeau \& } \\
\text { Lasker (1989) } \\
\text { Kinzie (1970) }\end{array}$ \\
\hline $\begin{array}{l}\text { Pseudopterogoria } \\
\text { bipinnata }\end{array}$ & External & External & - & - & - & - & 7 & - & - & Kinzie (1970) \\
\hline$P$, elisabethae & Unknown & - & - & - & - & - & 7 & - & - & Kinzie (1970) \\
\hline $\begin{array}{l}\text { Briareum } \\
\text { asbestinum }\end{array}$ & $\begin{array}{l}\text { Surface } \\
\text { brooding }\end{array}$ & Internal & $2.2: 1$ & $11-12$ & 5 & $600-900$ & 2.25 & $10-20$ & $2-3$ & $\begin{array}{l}\text { Brazeau \& } \\
\text { Lasker (1990) }\end{array}$ \\
\hline
\end{tabular}


Lasker 1990) and P. fulvum fulvum (Benayahu \& Loya 1983), while Farrant (1986) considered fertilization to be external in Capnella gaboensis. In any event, even if fertilization is external, from a strategic standpoint (investment in gametes, likelihood of fertilization, dispersal of larvae), the fertilization of eggs while they are still attached to the mother colony is closer to a viviparous strategy than to an oviparous strategy.

Nevertheless, since there is no cellular attachment between the embryos and the colonies, cell division takes place on the outer surface of the female colonies, and to that extent the strategies of the 4 species referred to above are quite distinct from the behaviour customary in other anthozoans, which brood their embryos on the surface of the colonies. This mode of reproduction is uncommon among coelenterates: it has only been described in 3 of 42 species of alcyonaceans studied (Farrant 1985, 1986, Benayahu et al. 1990), and in only 16 of 800 actinian species from around the world (Carlgren 1949). Among gorgonians, Paramuricea clavata is the second instance of surface brooding found among 10 species studied, the other being Briareum asbestinum (Brazeau \& Lasker 1990), as already mentioned above.

Although the number of species studied to date has been small, the evidence for gorgonians tends to reinforce the view that viviparity is an adaptation to harsh environments (Giese et al. 1987): fertilization is usually external in tropical gorgonian species (that have been studied to date), which release their gametes into the water (broadcasting), whereas fertilization tends to be internal in the viviparous temperate-water species (Table 2).

\section{Spawning synchrony}

Compression of spawning by the entire population into a short period around the same time each year is common among tropical coelenterates but less common among temperate-water species. Synchrony suggests an internal clock regulated by external stimuli. The main factors that have been related to spawning in gorgonians are temperature (Grigg 1977) and the lunar cycle (Brazeau \& Lasker 1989, 1990). Vighi (1970) described late gonadal development in deepsea populations of Corallium rubrum that was ascribed to lower water temperatures at those depths. Weinberg \& Weinberg (1979) noted that surface colonies of Eunicella singularis spawned before deep-water colonies and suggested that higher surface-water temperatures might be the cause. Grigg (1977) reported a similar phenomenon and put forward this same interpretation for Muricea fruticosa and M. californica off the coast of California (temperate waters).
Brazeau \& Lasker (1989) published the first report of synchronous spawning in the as yet taxonomically unclassified gorgonian species Plexaura A in tropical waters. Subsequently, those same workers found the same phenomenon in Briareum asbestinum (Brazeau \& Lasker 1990). They suggested that the lunar cycle played a basic role in determining the timing of synchronous spawning in both cases.

In all 3 years of observation Paramuricea clavata began spawning between 9 and 18 June, a period which coincided with a marked increase in water temperature towards the end of May in the area (Fig. 8). This behaviour was similar to that of colonies of Eunicella singularis, wherein colonies also commenced spawning around mid-June (19, 8 and 13 June in 1976, 1977 and 1978, respectively) (Weinberg \& Weinberg 1979), off Banyuls-sur-Mer, a nearby area where the temperature cycle is similar to that of the Medes Islands area. However this correlation between rising sea water temperatures and spawning does not imply a clear relationship of cause and effect. On the other hand, once the process is under way, the lunar cycle appears to take on considerable importance as a means of synchronizing the discrete periods (usually 2) in which spawning actually takes place. Nevertheless, confirmation of this hypothesis will require more observation.

The reproductive mechanism described protects embryos from such causes of mechanical damage as abrasion by the sediment or wave action; in addition, it enables larvae to develop to the planula stage near the mother colony. Furthermore, on release the larvae tended to settle near the adult colonies because of their negative bouyancy, which can be interpreted as a mechanism for conserving local populations rather than as a mechanism for dispersion.

In conclusion, the reproductive strategy observed in Paramuricea clavata appears to be consistent with that of a long-lived species occupying highly saturated, stable environments, with the exception of the low incidence of asexual reproduction (Hughes \& Cancino 1985, Jackson 1985). In contrast to tropical gorgonians, in which asexual reproduction is an important feature, P. clavata bases the maintenance of its populations on sexual reproduction. The strategy of this species appears to be designed to maximize the return on each year's investment in sexual reproduction. In fact, in unpredictable biotic environments such as the sublittoral communities where $P$. clavata grows, the advantages of sexual reproduction are paramount (Bell 1982). Successful fertilization is ensured by compressing synchronous episodes of spawning into a relatively discrete period of time and by retaining the eggs on the colony and thus adjacent to male colonies. Embryonic development and larval formation on the surface 
of the colonies enhances the likelihood of settlement of larvae in the vicinity of the colonies in the parent population. The short free-living existence of larvae and their limited locomotive capability contributes to the stability of local populations by hastening recruitment and concentrating it in the same habitat occupied by the adult colonies.

Acknowledgements. The authors gratefully acknowledge the helpful assistance of the colleagues who collaborated in the Medes Islands research programme. We also thank Dr V. Alvà, Dr R. G. Hughes and H. R. Lasker for their critical reviews of the manuscript. The authors are also grateful to 3 anonymous reviewers whose comments improved this paper. Also, thanks to Mr R. Sacks and Dr M. MacLean for their help in preparing the English version. This work was supported by CICYT grant, contract number PB91-0906.

\section{LITERATURE CITED}

Behety-González, P. A., Guardiola, M. (1979). Ciclo reproductivo de Plexaura homomalla (Esper, 1792) forma kuekenthali Moser, 1921 (Gorgonacea). Acad. Cienc. Cuba, Ser. Biol. 3: 99-104

Bell, G. (1982). The masterpiece of nature: the genetics and evolution of sexuality. University of California Press, Berkeley

Benayahu, Y., Loya, Y. (1983). Surface brooding in the red sea soft coral Parerythropodium fulvum fulvum (Forskål, 1775). Biol. Bull. 165: 353-369

Benayahu, Y., Loya, Y. (1984). Life history studies on the red sea soft coral Xenia macrospiculata Gohar, 1940. I. Annual dynamics of gonadal development. Biol. Bull. 166: 32-43

Benayahu, Y., Loya, Y. (1986). Sexual reproduction of a soft coral: synchronous and brief annual spawning of Sarcophyton glaucum (Quoy \& Gaimard, 1833), Biol. Bull. 170: $32-42$

Benayahu, Y., Weil, D., Kleinman, M. (1990). Radiation of broadcasting and brooding patterns in coral reef alcyonaceans. In: Hoshi, M., Yamashita, O. (eds.) Advances in invertebrate reproduction. Elsevier Science Publishers B. V. (Biomed. Div.), Amsterdam, p. 323-328

Bhattacharya, C. G. (1967). A simple method of resolution of a distribution into Gaussian components. Biometrics 23: $115-135$

Brazeau, D. A., Lasker, H. R. (1989). The reproductive cycle and spawning in a Caribbean gorgonian. Biol. Bull. 176: 1-7

Brazeau, D. A., Lasker, H. R. (1990). Sexual reproduction and external brooding by the Caribbean gorgonian Briareum asbestinum. Mar. Biol. 104: 465-474

Carlgren, O. (1949). A survey of the Ptychodactiaria, Corallimorpharia, and Actinaria. K. Svenska Vetenskap. Handl. 1: $1-120$

Coma, R. (1994). Evaluación del valance energético de dos especies de cnidarios bentónicos marinos. Ph.D. thesis, University of Barcelona

Farrant, P. A. (1985). Reproduction in the temperate Australian soft coral Capnella gaboensis. Proc. 5th int. coral Reef Congr. 4: 319-324

Farrant, P. A. (1986). Gonad development and the planulae of the temperate Australian soft coral Capnella gaboensis. Mar. Biol. 92: 381-392

Gayanilo, F. C., Soriano, M., Pauly, D. (1989). A draft guide to the complete ELEFAN. ICLARM Software, Manila
Giese, A. C., Pearse, J. S., Pearse, U. B. (1987). Reproduction of marine invertebrates. IX. General aspects: seeking unity in diversity. Blackwell Scientific Publications, Oxford

Goldberg, W., Hamilton, R. (1974). The sexual cycle in Plexaura homomalla. In: Bayer, F. M., Weinheimer, A. J. (eds.) Prostaglandins from Plexaura homomalla: ecology, utilization, and conservation of a major medical marine resource. University of Miami Press, Coral Gables, p. 58-61

Grigg, R. W. (1977). Population dynamics of two gorgonian corals. Ecology 58: 278-290

Harrison, P. S., Wallace, C. C. (1990). Reproduction, dispersal and recruitment of scleractinian corals. In: Dubinsky, $\mathrm{Z}$. (ed.) Ecosystems of the world. Elsevier, Amsterdam, p. 133-204

Hughes, R. N., Cancino, J. M. (1985). An ecological overview of cloning in Metazoa. In: Jackson, J. B. C., Buss, L. W., Cook, R. E. (eds.) Population biology and evolution of clonal organisms. Yale University Press, New Haven, p. $153-186$

Hughes, T. P. (1985). Life histories and population dynamics of early successional corals. Proc. 5 th int. coral Reef Congr. 4: 101-106

Hughes, T. P., Jackson, J. B. C. (1980). Do corals lie about their age? A reef-coral analysis. Am. Nat. 129: 818-829

Jackson, J. B, C. (1977). Competition on marine hard substrata: the adaptative significance of solitary and colonial strategies. Am. Nat. 111: 743-767

Jackson, J. B. C. (1985). Distribution and ecology of clonal and aclonal benthic invertebrates. In: Jackson, J. B. C., Buss, L. W., Cook, R. E. (eds.) Population biology and evolution of clonal organisms. Yale University Press, New Haven, p. 297-355

Kinzie, R. A. (1970). The ecology of the gorgonians (Cnidaria, Octocorallia) of Discovery Bay, Jamaica. Ph.D, thesis, Yale University, New Haven

Kinzie, R. A. (1974). Plexaura homomalla: the biology and ecology of a harvestable marine resource. In: Bayer, F. M., Weinheimer, A. J. (eds.) Prostaglandins from Plesuara homomalla. University of Miami Press, Coral Gables, p. $22-57$

Kojis, B. L., Quinn, N. J. (1981). Aspects of sexual reproduction and larval development in the shallow water hermatypic coral, Goniastrea australensis (Edwards and Haime, 1857) Bull. mar. Sci. 31: 558-573

Kojis, B. L., Quinn, N. J. (1982). Reproductive ecology of two Faviid corals (Coelenterata: Scleractinia). Mar. Ecol. Prog. Ser. 8: 251-255

Lasker, H. R. (1983). Vegetative reproduction in the octocoral Briareum asbestinum (Pallas). J. exp. mar. Biol. Ecol. 72: $157-169$

Lasker, H. R. (1984). Asexual reproduction, fragmentation and skeletal morphology of a plexaurid gorgonian. Mar. Ecol. Prog. Ser. 19: 261-268

Margalef, R. (1984). Ecología. Omega, Barcelona

Martin, E. (1982). Ciclo reproductivo, proporción sexual y fecundidad del coral blando Plexaura homomalla (Esper.) en el Mar Caribe Mexicano. (Octocoralla: Plexauridae). An. Inst. Cienc. Mar Limnol. Univ. Nal. Autón. Mexico 9: $359-380$

Pascual, J., Flos, J. (1984). Meteorologia i Oceanografia. In: Ros, J. D., Olivella, I., Gili, J. M. (eds.) Els Sistemes Naturals de les illes Medes, Atxius Sec. Ciènc. Inst. Estudis Catalans, Barcelona 73: 75-114

Sebens, K. P. (1982). Competition for space: growth rate, reproductive effort, and escape in size. Am. Nat. 120: 189-97 
Strathmann, R. R. (1980). Why does a larva swim so long? Paleobiology 6: 373-376

Szmant, A. M. (1986). Reproductive ecology of Caribbean reef corals. Coral Reefs 5: 43-53

Theodor, J. (1967). Contribution a l'étude des gorgones. VII. Ecologie et comportement de la planula. Vie Milieu 18: 291-301

Thorson, G. (1950). Reproduction and larval ecology of marine bottom invertebrates. Biol. Rev. 25: 1-45

This article was submitted to the editor
Vighi, M. (1970). Ricerche sul ciclo reproductivo del corallo rosso (Corallium rubrum (L.)) del Promontorio di Porfino. Atti. Accad. Lincei. Roma (Ser. 8) 10: 1-26

Walker, T. A., Bull, G. D. (1983). A newly discovered method of reproduction in gorgonian coral. Mar. Ecol. Prog. Ser. 12: $137-143$

Weinberg, S., Weinberg, F. (1979). The life cycle of a gorgonian: Eunicella singularis (Esper, 1794). Bijdr. Dierk. 48: $127-140$

Manuscript first received: April 6, 1994

Revised version accepted: October 13, 1994 